\title{
Opening the "black box" of nodD3, nodD4 and nodD5 genes of Rhizobium tropici strain CIAT 899
}

Pablo del Cerro ${ }^{1}$, Amanda Alves Paiva Rolla-Santos², Douglas Fabiano Gomes², Bettina Berquó Marks²,

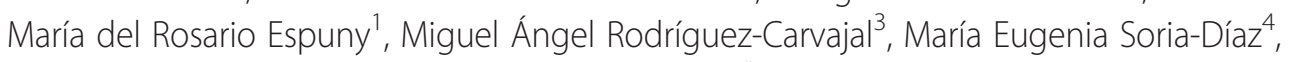
André Shigueyoshi Nakatani ${ }^{2}$, Mariangela Hungria ${ }^{2 *}$, Francisco Javier Ollero ${ }^{1}$ and Manuel Megías ${ }^{1}$

\begin{abstract}
Background: Transcription of nodulation genes in rhizobial species is orchestrated by the regulatory nodD gene. Rhizobium tropici strain CIAT 899 is an intriguing species in possessing features such as broad host range, high tolerance of abiotic stresses and, especially, by carrying the highest known number of nodD genes - five-and the greatest diversity of Nod factors (lipochitooligosaccharides, LCOs). Here we shed light on the roles of the multiple nodD genes of CIAT 899 by reporting, for the first time, results obtained with nodD3, nodD4 and nodD5 mutants.

Methods: The three nodD mutants were built by insertion of $\Omega$ interposon. Nod factors were purified and identified by LC-MS/MS analyses. In addition, nodD1 and nodC relative gene expressions were measured by quantitative RT-PCR in the wt and derivative mutant strains. Phenotypic traits such as exopolysaccharide (EPS), lipopolysaccharide (LPS), swimming and swarming motilities, biofilm formation and indole acetid acid (IAA) production were also perfomed. All these experiments were carried out in presence of both inducers of CIAT 899, apigenin and salt. Finally, nodulation assays were evaluated in up to six different legumes, including common bean (Phaseolus vulgaris L.).

Results: Phenotypic and symbiotic properties, Nod factors and gene expression of nodD3, nodD4 and nodD5 mutants were compared with those of the wild-type (WT) CIAT 899, both in the presence and in the absence of the nod-geneinducing molecule apigenin and of saline stress. No differences between the mutants and the WT were observed in exopolysaccharide (EPS) and lipopolysaccharide (LPS) profiles, motility, indole acetic acid (IAA) synthesis or biofilm production, either in the presence, or in the absence of inducers. Nodulation studies demonstrated the most complex regulatory system described so far, requiring from one (Leucaena leucocephala, Lotus burtii) to four (Lotus japonicus) nodD genes. Up to 38 different structures of Nod factors were detected, being higher under salt stress, except for the nodD5 mutant; in addition, a high number of structures was synthesized by the nodD4 mutant in the absence of any inducer. Probable activator (nodD3 and nodD5) or repressor roles (nodD4), possibly via nodD1 and/or nodD2, were attributed to the three nodD genes. Expression of nodC, nodD1 and each nodD studied by RT-qPCR confirmed that nodD3 is an activator of nodD1, both in the presence of apigenin and salt stress. In contrast, nodD4 might be an inducer with apigenin and a repressor under saline stress, whereas nodD5 was an inducer under both conditions. (Continued on next page)
\end{abstract}

\footnotetext{
* Correspondence: mariangela.hungria@embrapa.br

²Embrapa Soja, C.P. 231, 86001-970 Londrina, Paraná, Brazil

Full list of author information is available at the end of the article
}

(c) 2015 del Cerro et al. Open Access This article is distributed under the terms of the Creative Commons Attribution 4.0 International License (http://creativecommons.org/licenses/by/4.0/), which permits unrestricted use, distribution, and reproduction in any medium, provided you give appropriate credit to the original author(s) and the source, provide a link to the Creative Commons license, and indicate if changes were made. The Creative Commons Public Domain Dedication waiver (http://creativecommons.org/publicdomain/zero/1.0/) applies to the data made available in this article, unless otherwise stated. 
(Continued from previous page)

Conclusions: We report for $R$. tropici CIAT 899 the most complex model of regulation of nodulation genes described so far. Five nodD genes performed different roles depending on the host plant and the inducing environment. Nodulation required from one to four nodD genes, depending on the host legume. nodD3 and nodD5 were identified as activators of the nodD1 gene, whereas, for the first time, it was shown that a regulatory nodD gene—-nodD4—might act as repressor or inducer, depending on the inducing environment, giving support to the hypothesis that nodD roles go beyond nodulation, in terms of responses to abiotic stresses.

Keywords: Biological nitrogen fixation, LCO, nodD gene, Nod factors, Symbiosis

\section{Background}

The association of rhizobial strains and legumes represents one of the most perfect symbiotic interactions, in which a sophisticated machinery has been developed in both partners for millions of years, now contributing the highest inputs of nitrogen on Earth [1-4]. A fascinating step in the symbiosis is represented by the molecular signal dialogue established between the compatible partners, starting with the message sent with the exudation of molecules-mainly flavonoids-from the host legume, and replied with the synthesis of lipochitooligosaccharides (LCOs) - also known as Nod factors-by the rhizobium [5-10]. The "maestro" that orchestrates this symphony in the bacterium is the regulatory nodD gene, constitutively expressed and responsible for initiating the transcriptions of the remaining nodulation genes [9-12].

Rhizobium tropici is abundantly found in tropical acid soils of South America; its main characteristics are high tolerance of environmental stresses and ability to nodulate a broad range of legumes, the most economically important being common bean (Phaseolus vulgaris L.) [13-16]. Probably the most intriguing feature of the common bean- $R$. tropici symbiosis is the abundance of flavonoid nod-gene inducers released by the host legume [17, 18], and the synthesis of the largest known variety of Nod factors by $R$. tropici CIAT 899 [19-23]. Also unique are the observations that $R$. tropici CIAT 899 is capable of producing LCOs under abiotic stresses-such as acidic and saline conditions-in the absence of plant-molecular signals [20-23], and interestingly, some LCOs are produced even in the absence of saline stress and flavonoids [23].

Rhizobial species described so far have one to five regulatory nodD genes. $R$. tropici CIAT 899 and closely related species carrying the symbiovar tropici $(R$. leucaenae CFN 299, $R$. freirei PRF 81) possess the highest numbers, with five copies of nodD genes [24, 25]. Elucidating the roles of the five nodD genes of CIAT 899 may help to understand their protagonism in host-range characteristics and in the strategies that the strain uses to circumvent abiotic stresses. It may also contribute to gaining a better understanding of the evolution of symbiotic interactions, since $R$. tropici has a strong resemblance to the pathogen Agrobacterium in terms of genes and proteins [25, 26].

As a first study, we shed light on the roles of nodD1 and nodD2 of $R$. tropici CIAT 899, with data related to the activation/repression of nodulation genes, their role
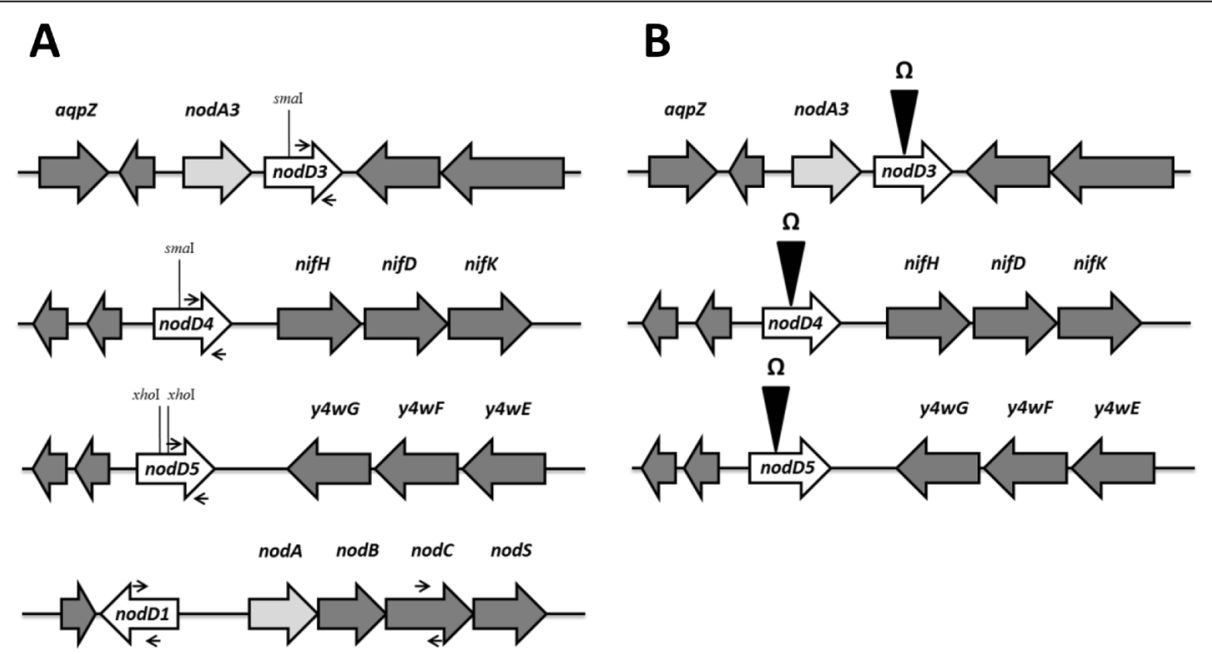

Fig. 1 Gene neighborhood of nodD3, nodD4 and nodD5 genes and representation of the mutations. a Gene localizationin the symbiotic plasmid (pRtCIAT899b) of R. tropici strain CIAT 899 and location of primers used to perform RTqPCR experiments (dark arrows); b Schematic representation of the nodD3, nodD4 and nodD5 mutation 
in host range and showing that these two genes have functions beyond nodulation [23]. Here we achieve improved understanding of the mechanisms controlling regulation of the nodD genes of CIAT 899, with studies of nodD3, nodD4 and nodD5 mutants.

\section{Results and discussion}

Gene localization and phenotypes in vitro of the wild type and mutant strains

nodD gene nomenclature was used as defined for the genome of $R$. tropici strain CIAT 899 [25]. nodA3 precedes nodD3 and is close to an aquaporin; nodD4 precedes the operon nifHDK and nodD5 is downstream of an operon of hypothetical proteins (Fig. 1). nodD3, nodD4 and nodD5 genes correspond to the CD5, CD21 and CD29 nodD-hybridizing regions of CIAT 899 described by van Rhijn et al. [24], respectively. Mutations in the nodD3, nodD4 and nodD5 genes were achieved as described in the Methods section. In general, evaluations were performed in the absence of any inducer ( $\mathrm{B}^{-}$medium) [20], in the presence of the nod-gene-inducing molecule apigenin $(3.7 \mu \mathrm{M})$, or under salinity stress $(\mathrm{NaCl} 300 \mathrm{mM})$ that also induce the synthesis of Nod factors. The same treatments were used in our previous study with nodD1 and nodD2 mutants [23].

Some bacterial properties may be regulated via NodD proteins, and in our previous study we showed that both nodD1 and nodD2 have a constitutive suppression role on swarming motility and an activation effect on indole acetic acid (IAA) synthesis [23]. Here, we found no differences between the three mutants and the WT strain in exopolysaccharide (EPS) and lipopolysaccharide (LPS) profiles, swimming and swarming motilities, biofilm formation, or IAA synthesis (data not shown).

\section{Symbiotic phenotypes}

Symbiotic phenotypes of the WT CIAT 899 and the mutant strains were verified in pots containing sterile substrate (Leonard jars). Previously, we reported that common bean requires both nodD1 and nodD2, whereas nodD1 was the main nodulation regulator of both leucaena [Leucanea leucocephala (Lam.) de Wit] and siratro [Macroptilium atropurpureum (DC.) Urb.] [23]. For comparison, these results are shown again in Table 1, together with the results obtained with nodD3, nodD4 and nodD5 mutants; in addition, the symbiotic properties of all five nodD mutants were assayed in two other host legumes, Lotus burtii Borsos and Lotus japonicus (Regel) K. Larsen.

For the common bean, there were no statistical differences between the WT and the three mutants in terms of the nodulation or shoot dry weight (SDW) parameters, but we should mention that there was a decrease in nodulation, which might indicate effects of minor magnitude due to the mutations, with an emphasis on nodD5, where it also affected SDW. Leucaena and siratro also did not show differences in nodulation between the WT and the three mutants, but SDW of leucaena inoculated with nodD4 and nodD5 mutants was slightly, but significantly, lower (Table 1).

In relation to the nodulation of Lotus species, nodD1 was the main regulator in $L$. japonicus and very important

Table 1 Plant responses (nodule number, n\%plant) and shoot dry weight ( $\mathrm{g} / \mathrm{pl}$ ) to inoculation of common bean, leucaena, siratro, Lotus japonicus and L. burtii with R. tropici strain CIAT 899 and derivatives. Plants evaluated after 25 (common bean.), 42 days (leucaena and siratro), or 50 days (Lotus spp.) of growth under controlled conditions

\begin{tabular}{|c|c|c|c|c|c|c|c|c|c|c|}
\hline \multirow[t]{2}{*}{ Strains } & \multicolumn{2}{|l|}{ P. vulgaris } & \multicolumn{2}{|c|}{ L. leucocephala } & \multicolumn{2}{|c|}{ M. atropurpureum } & \multicolumn{2}{|c|}{ L. japonicus } & \multicolumn{2}{|l|}{ L. burtii } \\
\hline & $\begin{array}{l}\text { Nodule } \\
\text { number }\end{array}$ & $\begin{array}{l}\text { Shoot dry } \\
\text { weight }\end{array}$ & $\begin{array}{l}\text { Nodule } \\
\text { number }\end{array}$ & $\begin{array}{l}\text { Shoot dry } \\
\text { weight }\end{array}$ & $\begin{array}{l}\text { Nodule } \\
\text { number }\end{array}$ & $\begin{array}{l}\text { Shoot dry } \\
\text { weight }\end{array}$ & $\begin{array}{l}\text { Nodule } \\
\text { number }\end{array}$ & $\begin{array}{l}\text { Shoot dry } \\
\text { weight }\end{array}$ & $\begin{array}{l}\text { Nodule } \\
\text { number }\end{array}$ & $\begin{array}{l}\text { Shoot dry } \\
\text { weight }\end{array}$ \\
\hline $\begin{array}{l}\text { R. tropici } \\
\text { CIAT } 899\end{array}$ & $213 \pm 52^{\mathrm{a}}$ & $1.82 \pm 0.64^{\mathrm{a}}$ & $13 \pm 4^{a}$ & $0.41 \pm 0.03^{\mathrm{a}}$ & $34 \pm 8^{a}$ & $0.05 \pm 0.01^{a}$ & $22 \pm 9$ & $0.064 \pm 0.03$ & $11 \pm 5$ & $0.04 \pm 0.02$ \\
\hline $\begin{array}{l}\text { nodD1 } \\
\text { mutant }\end{array}$ & $38 \pm 11^{*, a}$ & $1.42 \pm 0.35^{\mathrm{a}}$ & $0 \pm 0^{*}, a$ & $0.09 \pm 0.01^{*, a}$ & $0 \pm 0^{*}, \mathrm{a}$ & $0.05 \pm 0^{\mathrm{a}}$ & $0 \pm 0^{*}$ & $0.007 \pm 0.004^{*}$ & $5 \pm 2^{*}$ & $0.04 \pm 0.02$ \\
\hline $\begin{array}{l}\text { nodD2 } \\
\text { mutant }\end{array}$ & $95 \pm 38^{*, a}$ & $1.03 \pm 0.27^{a}$ & $10 \pm 3^{a}$ & $0.36 \pm 0.04^{* *, a}$ & $24 \pm 8^{a}$ & $0.05 \pm 0^{\mathrm{a}}$ & $30 \pm 10$ & $0.039 \pm 0.013^{*}$ & $12 \pm 5$ & $0.03 \pm 0.01$ \\
\hline $\begin{array}{l}\text { nodD3 } \\
\text { mutant }\end{array}$ & $182 \pm 25$ & $1.80 \pm 0.34$ & $13 \pm 3$ & $0.39 \pm 0.09$ & $38 \pm 12$ & $0.05 \pm 0$ & $12 \pm 4^{*}$ & $0.025 \pm 0.014^{*}$ & $9 \pm 4$ & $0.04 \pm 0.01$ \\
\hline $\begin{array}{l}\text { nodD4 } \\
\text { mutant }\end{array}$ & $190 \pm 24$ & $1.84 \pm 0.5$ & $14 \pm 3$ & $0.37 \pm 0.01^{*}$ & $29 \pm 8$ & $0.05 \pm 0$ & $17 \pm 6$ & $0.058 \pm 0.052$ & $12 \pm 5$ & $0.03 \pm 0.02$ \\
\hline $\begin{array}{l}\text { nodD5 } \\
\text { mutant }\end{array}$ & $179 \pm 16$ & $1.45 \pm 0.68$ & $12 \pm 4$ & $0.37 \pm 0.01^{*}$ & \pm 7 & .01 & $6 \pm 2^{*}$ & $0.021 \pm 0.011^{*}$ & $12 \pm 2$ & $0.05 \pm 0.01$ \\
\hline None & $0 \pm 0^{*}$ & $0.80 \pm 0.25^{*}$ & $0 \pm 0^{*}$ & $0.09 \pm 0.01^{*}$ & $0 \pm 0^{*}$ & $0.05 \pm 0$ & $0 \pm 0^{*}$ & $0.008 \pm 0.004^{*}$ & $0 \pm 0^{*}$ & $0.01 \pm 0^{*}$ \\
\hline
\end{tabular}

${ }^{\mathrm{a}}$ After [23]

*Data represent means \pm SD (standard deviation) of 6 jars, each with two plants. nodD3, nodD4 and nodD5 mutant parameters were individually compared with the parental strain CIAT 899 parameters by using the Mann-Whitney non-parametric test. Values tagged by ${ }^{*}$ and ${ }^{* *}$ are significantly different at the level $a=10$ and $5 \%$, respectively 
for $L$. burtii, whereas nodD2 did not affect nodulation but resulted in a significative reduction in SDW of L. japonicus, indicating that it interferes with the efficiency of nitrogen fixation. In addition, for L. japonicus, a mutation in nodD3 and nodD5 also affected nodulation and SDW, whereas no effects were observed for $L$. burtii (Table 1).

From these data, we may conclude that full nodulation of common bean requires both nodD1 and nodD2 genes, but it is possible that nodD3 and nodD5 could make minor contributions that were not statistically detected in our experiments. Therefore, as in several other rhizobial species $[27,28]$ including the broadly nodulating S. fredii NGR 234 [29], nodD1 is the main gene regulating nodulation of leucaena, siratro, L. burtii and L. japonicus. Siratro does not require any other nodD gene for nodulation, but a non-statistically significant decrease observed with the nodD2 mutant should be more fully investigated. Lotus burtii does not require any of the nodD genes except for nodD1. In contrast, L. japonicus receives contributions from all the nod genes except for nodD4 for nodulation, because with the other nodD mutants a reduced SDW was observed (Table 1).

The most intricate pattern of responses in nodulation described so far is that for Sinorhizobium meliloti, which utilizes the three copies of nodD to optimize nodulation of each of its legume hosts [27]. However, now we present a regulatory pattern that involves from one nodD gene (leucaena, L. burtii) to four (L. japonicus). There were also indications that nodD genes influence nodule effectiveness, as shown for nodD2, nodD4 and nodD5 for leucaena, and nodD2 for L. japonicus. Another particularity for $R$. tropici CIAT 899 was that, in general, nodD2 was not a repressor of any of the legumes evaluated, contrary to what happens with the broadly nodulating strain NGR 234 [30].

\section{Nod-factor patterns}

The interesting roles of Nod factors-which apparently can go further than nodulation-have been broadly investigated over a long period of time $[5,8,10,12,31] . R$. tropici CIAT 899 synthesises a large variety of Nod factors when induced by flavonoids [19-23], or under abiotic

Table 2 Number of Nod factors produced by the wild type $R$. tropici strain CIAT 899 and the nodD3, nodD4 and nodD5 mutants when grown in control $\mathrm{B}^{-}$medium [20], with $3.4 \mu \mathrm{M}$ of apigenin or salt ( $\mathrm{NaCl} 300 \mathrm{mM})$. The structures of Nod factors under each condition are shown in Additional file 1: Table S1, Additional file 2: Table S2 and Additional file 3: Table S3

\begin{tabular}{llll}
\hline & $B^{-}$medium & Apigenin & Salt \\
\hline CIAT 899 - WT & 11 & 29 & 36 \\
nodD3 & 2 & 21 & 25 \\
nodD4 & 15 & 22 & 38 \\
nodD5 & 8 & 30 & 26 \\
\hline
\end{tabular}

stress conditions in the absence of flavonoids [2023]; surprisingly, Nod factors are also synthesized in the absence of any known inducer [23].

A variety of Nod-factor structures was synthesized by the nodD3, nodD4 and nodD5 mutants (Additional file 1: Table S1, Additional file 2: Table S2 and Additional file 3: Table S3). nodD3 mutant reduced the number of Nod factors under all three conditions, control, when induced with apigenin and uneder saline conditions, while nodD5 mutant had a decrease in the number of Nod factors under control and saline conditions (Table 2). It is noteworthy that nodD4 increased the number of Nod factors in under salinity, without the induction of apigenin. The larger number of Nod factors was observed under saline conditions for the WT and nodD4 mutants, whereas similar numbers were observed with apigenin (Table 2). These results add more evidence to the hypothesis that the large production of Nod factors is related to the well known properties of broad host infectivity and the high tolerance of abiotic stresses of $R$. tropici, being able to establish symbioses even under harsh environmental conditions [13-16].

In relation to the Nod-factor structures, the mutations in nodD3 in general did not result in changes in the molecules produced both in the presence of apigenin and salt. However, in the negative control $\mathrm{B}^{-}$, the number of molecules was drastically reduced, which indicates that nodD3 might be an activator of other regulatory genes such as nodD1 (Additional file 1: Table S1, Additional file 2: Table S2 and Additional file 3: Table S3). Moreover, CIAT 899 produced only two Nod factors deacetyled in the presence of apigenin $\left[\mathrm{V}\left(\mathrm{C}_{18: 1}\right) \mathrm{dNAc}\right.$ and $\mathrm{V}\left(\mathrm{C}_{18: 1}, \mathrm{NMe}\right)$ dNAc]. However, the nodD3 mutant produced five deacetyled Nod factors that were not detected in the LCOs biosynthesized by the nodD4 and nodD5 mutants. These results suggest that the nodD3 gene is important for the deacetylation of Nod factors produced by CIAT 899 in the presence of apigenin. Non-deacetylated Nod factors were detected in control and saline conditions (Additional file 1: Table S1, Additional file 2: Table S2 and Additional file 3: Table S3). Interestingly, it has been suggested that hsnT (=noeT) has a role in Nod-factor decoration in Neorhizobium galegae [32].

Under saline stress, in addition to an increase in the LCOs synthesized by the nodD 4 mutant, fatty acids of $C_{14: 1}$ were not found, nor were sulphated molecules of four units of $\mathrm{N}$-acetyl-glucosamine. Not least important, the strong increase in the number of molecules in the nodD4 mutant might indicate that the gene is a repressor of other regulatory genes, such as nodD1 (Additional file 1: Table S1, Additional file 2: Table S2 and Additional file 3: Table S3).

For the nodD5 mutant, no quantitative or qualitative differences in LCOs were observed, whereas important 
differences were detected under saline stress. The mutation not only resulted in a decrease in the number of LCOs, but also the molecules included neither fatty acids $\mathrm{C}_{14: 0}$, nor sulphated molecules of 4 units of $\mathrm{N}$-acetylglucosamine. In addition, we did not detect the fatty acids $C_{20: 0}$ or $\mathrm{C}_{20: 1}-\mathrm{V}\left(\mathrm{C}_{20: 0}\right.$, NMe, $\left.\mathrm{S}\right) ; \mathrm{V}\left(\mathrm{C}_{20: 1}, \mathrm{NMe}\right)$ and $\mathrm{V}\left(\mathrm{C}_{20: 1}\right.$, $\mathrm{NMe}, \mathrm{S})$, found in the WT, nodD3 and nodD4 strains in the presence of salt. It is worth mentioning that nodD1 and nodD2 mutants also do not produce these factors in the presence of salt [23]. Fatty acids $C_{20: 0}$ or $C_{20: 1}$ under salt stress and/or $\mathrm{C}_{14: 0}$ o $\mathrm{C}_{14: 1}$ with apigenin might have the participation of genes detected in the genome of CIAT 899 [25], such as nodE and nodF genes [33]. Consequently, the absence of these fatty acids in nodD5 mutants under saline stress indicates that other regulatory nodD genes were not activated under salt, and nodD1 and nodD2 are strong candidates, as their mutants inhibited the synthesis of these fatty acids. We suggest that nodD5 could be an activator of nodD1 or nodD2 in the presence of salt to allow the expression of genes nodE-nodF.

This intricate regulatory mechanism for the production of LCOs involving five nodD genes-demonstrated in our study-seems to have no parallel in other rhizobia, especially under saline stress. As the tropical conditions where $R$. tropici is abundantly found are often extreme [34], this might indicate a high degree of evolution to allow the symbioses to form and function under harmful conditions. It is also worth mentioning that several other roles have been attributed to LCOs besides being involved in early steps of nodulation. For example, there are reports that LCO effects resemble those of cytokinins [29], that they have a role in mechanisms related to defense against
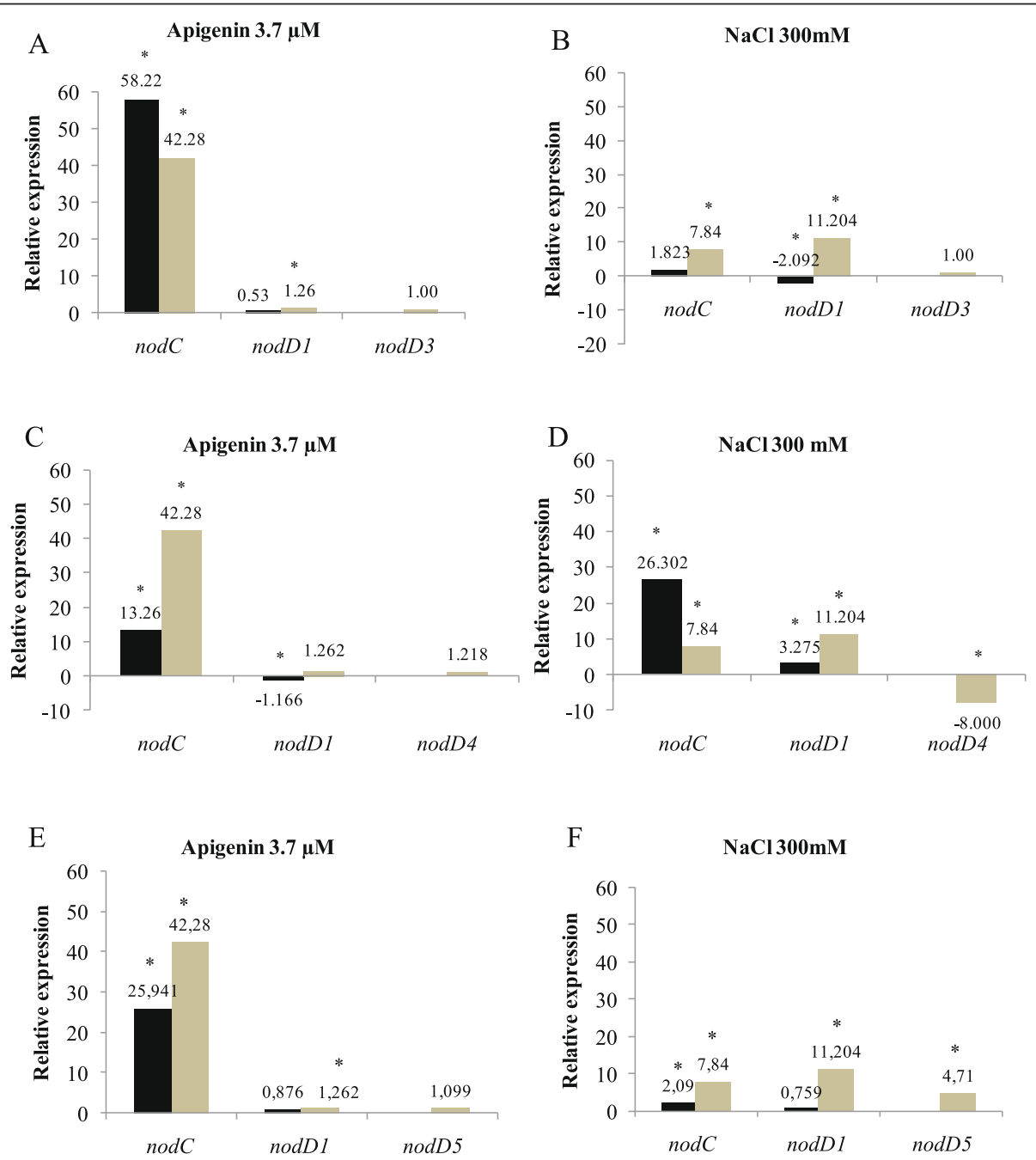

Fig. 2 RT-qPCR analysis of the expression of nodD genes from R. tropici CIAT 899 and derivatives grown under control (B- medium), in the absence and in the presence of apigenin $(3.7 \mu \mathrm{M})$ or $\mathrm{NaCl}(300 \mathrm{mM})$. Expression data shown are the mean ( \pm standard deviation of the mean) of three biological replicates. Data were normalized in relation to the endogenous control (16S rRNA). The asterisks indicate a statistically significant expression at the level $\mathbf{a}=5 \%$, determined by REST2009 software. Light gray bars: wild type strain, black bars: mutant. $\mathbf{a}, \mathbf{b}$ - expression induced in the nodD3 mutant; $\mathbf{c}, \mathbf{d}$ - expression induced in the nodD4 mutant; $\mathbf{e}, \mathbf{f}$ - expression induced in the nodD5 mutant 
disease [35, 36] and seed germination [37]; therefore, the role of LCO structure in phenotype determination deserves further investigation.

\section{Gene expression}

We performed gene-expression studies with the wild type and nodD3, nodD4 and nodD5 mutants. In these studies we evaluated the expression of nodC-which controls the elongation of the oligosaccharide chain of Nod factors and is transcribed with the activation of nod genes [8] - of the nodD1 gene and of each of the three nodD genes, to improve our understanding of the roles of these three genes. As expected, endogenous expression of all nodD genes was consistently low, as these genes are constitutively expressed. In addition, the expression of each nodD gene corresponding to each nodD mutation was confirmed as null (Fig. 2).

Significant expression of nodC for both the WT and the nodD3 mutant was verified, of 42- and 58-fold, respectively, when induced by apigenin, and, although at basal low levels, nodD1 expression was significantly increased in the WT strain (Fig. 2a). Under saline stress, a mutation in nodD3 decreased both nodC and nodD1 expression, confirming the results obtained with Nod factors, that nodD3 is an activator of nodD1, especially under saline conditions (Fig. 2b).

The picture obtained with nodD4 was somewhat different. A mutation in nodD4 resulted in a 3-fold decrease, but not in total inhibition of expression of nodC with apigenin; therefore, the results indicate an activation role in the presence of apigenin (Fig. 2c). However, in saline conditions, nodD4 expression in the WT strain was down-regulated, indicating a repressor role, that was confirmed by an increase of 3.35 -fold on nodC expression when the gene was mutated Fig. 2d. Therefore, under apigenin nodD4 acted as an activator and under salt stress as a repressor of other nod genes (Fig. 2c, d).

In relation to $\operatorname{nodD} 5$, the gene proved to be an inducer, increasing the expression of both nodC and nodD1 in the presence of both the inducer molecule apigenin (Fig. 2e) and salt stress (Fig. 2f). These results are consistent with the results based on the synthesis of Nod factors.

\section{Phylogeny of nodD genes}

A phylogenetic tree was built to verify the similarities between the five copies of nodD genes of CIAT 899, helping to add information about these genes. Figure 3 shows that nodD2 gene of CIAT 899 is positioned in a different cluster from the other nodD genes, showing full similarity with the nodD2 of $R$. freirei PRF 81 , that belongs to the " $R$. tropici group" [38]. Within the same great cluster of the phylogenetic tree, but positioned in another subgroup was the nodD3 genes of $R$. etli sv phaseoli. The other four copies of nodD genes of CIAT 899 were positioned in another great cluster, each one showing full identity with the correspondent nodD gene of $R$. freirei.

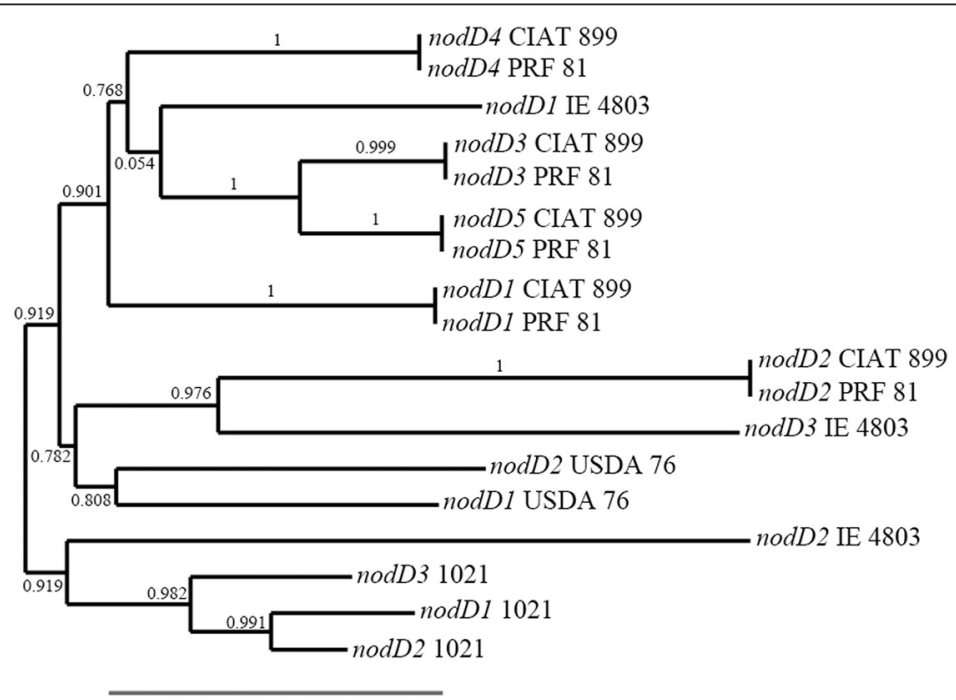

0.3

Fig. 3 Phylogenetic tree of representatives nodD genes of some relevant rizobia. The branchs length represents the evolutionary lineages changing over time. The length of the brach represents the amount of changes and it is proportional to the number of nucleotide substitutions per site. The bar at the bottom of the figure provides a scale for the evolution. The numbers next to each node represent a measure of support for the node (between 0 and 1). A high value means that there is strong evidence that the sequences to the right of the node cluster together to the exclusion of any other. Phylogenetic tree was built as described in the Methods section. In this phylogenetic tree, nodD1 to nodD5 CIAT 899 correspond to Rhizobium tropici CIAT 899 nodD genes; nodD1 to nodD5 PRF 81 correspond to Rhizobium freirei PRF 81 nodD genes; nodD1 to nodD3 IE 4803 correspond to Rhizobium etli sv. phaseoli IE 4803 nodD genes; nodD1 to nodD3 1021 correspond to Sinorhizobium meliloti 1021 nodD genes; and nodD1 and nodD2 USDA 76 correspond to Bradyrhizobium elkanii USDA 76 nodD genes. 
Therefore, apparently nodD2 had a different evolutionary history from the other nodD genes, and as we pointed out before, one important host legume, leucaena does not need nodD2 for full nodulation, while common bean does. One hypothesis is that nodD2 could have been acquired in the evolutionary process of getting the ability to nodulate common bean.

\section{Why five nodD genes?}

In contrast to what we have previously reported for nodD1 and nodD2 [23], nodD3, nodD4 and nodD5 of $R$. tropici CIAT 899 did not affect phenotypic traits such as motility or of IAA synthesis. However, they contributed to the intricate regulatory mechanism of nodulation of different host plants that, overall, may require from one to four genes. It remains to be determined if all five genes contribute to the nodulation of common bean, since minor, but not statistically significant, decreases in nodulation were observed with nodD3, nodD4 and nodD5 mutants.

Apparently the increased number of Nod factors and the activation of nodD1 and nodC genes under abiotic stress may be critical for nodulation under abiotic stresses or for enlargement of host range, guaranteeing the survival of both symbiotic partners under harsh environmental conditions. It is surprising that one major host, common bean, releases so many nod-gene-inducing molecules $[17,18,39]$ and that a main rhizobial symbiont synthesizes so many Nod factors by the action of five nodD genes. The results previously obtained with hosts such as leucaena and siratro-and now confirmed with Lotus spp.-where nodD1 played the major role adds weight to the hypothesis that common bean is not the main host for $R$. tropici [23]. One important observation was that the phylogenetic comparisons of nodD genes positioned nodD2 in a different cluster from the other nodD genes, what might indicate an evolution in the process of getting the ability to nodulate common bean, the requires both nodD1 and nodD2 genes, contrary to hosts as leucaena. Sharing the nodulation responsibility with more than one nodD gene, as is the case with common bean, suggests the ultimate evolution of the symbiosis, guaranteeing that nodulation occurs under abiotic stresses.

\section{Conclusions}

R. tropici CIAT 899 is an intriguing rhizobia with high tolerance of environmental stresses, the ability to nodulate a broad range of legume hosts and carrying five copies of the regulatory nodD gene [34]. The role of three $\operatorname{nodD}$ genes of CIAT 899 was investigated for the first time in this study. nodD3 and nodD5 were identified as activators of the nodD1 gene, whereas nodD4 might act as repressor or inducer, depending on the inducing environment. A large variety of Nod factors was produced by the three mutants when induced by apigenin or salt stress, and also in the absence of any inducer. We may hypothesize that the high number of nodD copies and the synthesis of many Nod factors might help $R$. tropici both in enhancing the host range and in the ability to nodulate the hosts under harsh environmental conditions.

\section{Methods}

Bacterial strains, plasmids, media, and growth conditions

Rhizobium tropici CIAT 899 and derivative strains (nodD3, nodD4 and nodD5 mutants) were grown at $28{ }^{\circ} \mathrm{C}$ on tryptone yeast (TY) medium [40], $\mathrm{B}^{-}$minimal medium [20] or yeast-extract mannitol (YM) medium [41], supplemented when necessary with apigenin to a final concentration of $3.7 \mu \mathrm{M}$ or with $\mathrm{NaCl}$ at $300 \mathrm{mM}$. Escherichia coli strains were cultured on Luria-Bertani (LB) medium [42] at $37{ }^{\circ} \mathrm{C}$. When required, the media were supplemented with the appropriate antibiotics as described by Lamrabet et al. [43]. The same strategy described before for obtaining nodD2 mutants of $R$. tropici CIAT 899 [23] was now used to obtain nodD3, nodD4 and nodD5 mutants by the insertion in the ORF of these genes of the $\Omega$ interposon (carrying the spectinomycin resistance gene $\left(\mathrm{spc}^{\mathrm{R}} 100 \mu \mathrm{g} \mathrm{mL} \mathrm{L}^{-1}\right)$. Briefly, pair primers nodD3-F (5' - GAG CTA CCT CGA CTG CTA) and nodD3-R ( $5^{\prime}$ - CTA CCG CCA TGA TCA CCA) were used for amplifying nodD3 gene. The 1500-bp PCR product was cloned in PGEM -T Easy (PROMEGA) $\left(\mathrm{Amp}^{\mathrm{R}} 100 \mu \mathrm{g} \mathrm{m}^{-1}\right.$ ). The PCR-amplified nodD3 fragment was cutted with the endonuclease SmaI, which cut the nodD3 gene in one site, disrupting it. The obtained DNA was ligated with $\Omega$, which was previously digested with the SmaI enzyme. The ligation mixture was transformed into $E$. coli strain DH5 $\alpha$. The nodD3:: $\Omega$ fragment $(3,5 \mathrm{~Kb})$ was excised from pGEM-T Easy with the endonuclease EcoRI and cloned in the vector pK18mob [44], that confers resistance to kanamycin $\left(\mathrm{km}^{\mathrm{R}} 30 \mu \mathrm{g} \mathrm{mL}^{-1}\right)$, equally restricted with EcoRI.

Pair primers nodD4-F (5' - CTG TCG CTC TGA TAT TCG A) and nodD4-R (5' - ATA GGA CAG CCT TGG CAA) were used for amplifying nodD4 gene. The 1497-bp PCR product was cloned in PGEM ${ }^{\circ}-\mathrm{T}$ Easy. The PCRamplified nodD4 fragment was excised from pGEM $^{\circ}$-T Easy with the endonuclease $E c o R I$ and cloned in the vector pK18mob equally restricted with EcoRI. In order to eliminate a SalI site in the polylinker of pK18mob, the plasmid was cut with SmaI and HindIII and religated. The plasmid containing the PCR-amplified nodD4 fragment was cut with the endonuclease Sall, which disrupt the nodD4 gene in one site and then was treated with the Klenow enzyme. The obtained DNA was ligated with the $\Omega$ interposon, which was previously digested with the SmaI enzyme. The ligation mixture was transformed into $E$. coli strain $\mathrm{DH} 5 \alpha$.

Pair primers nodD5-F (5' - GCT CTT TCT TTC CCA CCA A) and nodD5-R (5' - GAT CTG CCG ATG GCT CA) were used for amplifying nodD5 gene. The 1478-bp 
PCR product was cloned in pGEM ${ }^{\circ}-\mathrm{T}$ Easy. The PCRamplified nodD5 fragment was excised from pGEM $^{\circ}-\mathrm{T}$ Easy with the endonuclease EcoRI and cloned in the vector pK18mob equally restricted with EcoRI. This plasmid was digested with the enzyme XhoI, which cut the nodD5 gene in two sites, releasing a fragment of approximately $18 \mathrm{pb}$. Rest of the plasmid was treated with Klenow enzyme to convert the cohesive end generated by the enzyme to a blunt end. The obtained DNA was ligated with the $\Omega$ interposon, which was previously digested with the SmaI enzyme (blunt end). The ligation mixture was transformed into E. coli strain DH5 .

In all cases, plasmids harbouring mutation in the nodD3, nodD4 and nodD5 genes, were transferred from $E$. coli to Rhizobium strains by conjugation as described by Simon [45] using plasmid pRK2013 [46] as helper. The plasmid generated was used for the homogenotization of the mutated version of the nodDs gene in $R$. tropici CIAT 899 by using the methodology previously described [47]. The homogenotization was confirmed by DNA-DNA hybridization. For this purpose, DNA was blotted to Hybond-N nylon membranes (Amersham, UK), and the DigDNA method of Roche (Switzerland) was employed according to the manufacturer's instructions. A scheme of the mutation generated in the nodD3, nodD4 and nodD5 genes are shown in Fig. 1.

It is worth mentioning that growth rate was not affected by mutation in nodD3, nodD4, or nodD5 genes; in addition, for the target mutagenesis of nod genes external primers were chosen that would allow to specifically amplify both genes, what was possible because the intergenic regions flanking both genes have different sequences. Therefore, the different phenotypes observed in both mutants are caused by loss of function of these genes. The parental and mutant strains are deposited in the culture collection of the Department of Biology of the Universidad de Sevilla and at the Diazotrophic and Plant Growth Promoting Bacteria Culture Collection of Embrapa Soja (WFCC Collection \# 1213, WDCM Collection \# 1054).

\section{Identification of nod factors}

Purification and LC-MS/MS analyses of Nod factors produced by $R$. tropici CIAT 899 and derivative strains grown in $\mathrm{B}^{-}$minimal medium (supplemented when required with $\mathrm{NaCl} 300 \mathrm{mM}$ or apigenin $3.7 \mu \mathrm{M}$ ) were performed as described previously [22].

\section{RNA isolation, CDNA synthesis and quantitative RT-PCR}

Wild-type CIAT 899 and mutants strains were precultured in $10-\mathrm{mL}$ aliquots of TY medium at $100 \mathrm{rpm}$ and $28{ }^{\circ} \mathrm{C}$ in the dark. After $48 \mathrm{~h}$, the three strains preinoculated were transferred to new media and subjected to the following conditions: control (without induction),
$300 \mathrm{mM} \mathrm{NaCl}$ and apigenin $3.7 \mu \mathrm{M}$. These new cultures were performed in triplicate under the same conditions as for the pre-cultures, $100 \mathrm{rpm}$ and $28{ }^{\circ} \mathrm{C}$ in the dark, except that were grown into the exponential phase (O.D. at $600 \mathrm{~nm}$ of 0.5 to 0.6 ).

Total RNA was extraction, verification of concentration and integrity and synthesis of cDNA were performed as described before Primers for the RT-qPCR targets, genes nodD1, nodD3, nodD4, nodD5 and nodC, were designed using Primer3Plus (http://www.bioinformatics.nl/cgi-bin/ primer3plus/primer3plus.cgi/), to obtain amplicons of 50$150 \mathrm{bp}$. With the same software, a primer to 16S rRNA was obtained and applied to normalize the relative expression of the targets. To avoid unspecific alignments, the primer sequences were searched against the $R$. tropici CIAT 899 genome (http://www.ncbi.nlm.nih.gov/nuccore/ 440224888?report=genbank). The primer sequences and sizes of the amplified fragments are available in Additional file 4: Table S4. RT-qPCR reactions were performed as described before [23]. Rest2009 software package [48] was used to evaluate the data by providing a robust statistical analysis $(p<0.05)$. The normalization of cycle threshold (Ct) of RT-qPCR amplifications was performed based on the selected endogenous gene (16S rRNA).

\section{Phenotypic traits}

Analysis of exopolysaccharide (EPS), lipopolysaccharide (LPS), swimming and swarming phenotypes, biofilm formation and quantification of indole acetic acid (IAA) production were perfomed as described before [23].

\section{Nodulation assays}

For the evaluation of the symbiotic phenotypes, wild-type $R$. tropici strain CIAT 899 and nodD1, nodD2, nodD3, nodD4 and nodD5 mutants were grown in YM medium until a concentration of $10^{9}$ cells $\mathrm{mL}^{-1}$ was achieved, to be used as inoculum. Surface-sterilized seeds [41] were used for the assays with common bean (Phaseolus vulgaris L.), leucaena [Leucaena leucocephala (Lam.) de Wit] and siratro [Macroptilium atropurpureum (DC) Urb.], Lotus burtii Borsos, and Lotus japonicus (Regel) K.Larsen. Pregerminated seeds (about 2 days after germination) were placed in sterilized pouches or Leonard jars containing $\mathrm{N}$ free nutrient solution [41], with $1 \mathrm{~mL}$ of inoculum of each strain added and verified for nodulation capacity after 25 (common bean), 42 days (leucaena and siratro) and 50 days (Lotus japonicus and Lotus burtii) with a $16-\mathrm{h} 25^{\circ} \mathrm{C} / 18^{\circ} \mathrm{C}$ photoperiod and about $70 \%$ relative humidity. Shoots were dried at $65^{\circ} \mathrm{C}$ until constant weight was achieved, and then weighed. Experiments were performed three times.

\section{Phylogenetic tree construction}

Phylogenetic tree was obtained by using online plataform (http://phylogeny.lirmm.fr/phylo_cgi/) [49]. Nucleotide 
sequences of each nodD gene were first aligned by MUSCLE [50] and conserved blocks were selected [51]. The phylogenetic tree was obtained by suing the maximum-likehood algorithm $[52,53]$ and the TreeDyn for visualization [54].

\section{Additional files}

Additional file 1: Table S1. Nod Factor structure biosynthesized in control condition ( $\mathrm{B}^{-}$medium) by wild type CIAT 899 and derivatives. (DOC $45 \mathrm{~kb}$ )

Additional file 2: Table S2. Nod Factor structure biosynthesized in the presence of apigenin $(3.7 \mu \mathrm{M})$ by wild type CIAT 899 and derivatives. (DOC $72 \mathrm{~kb}$ )

Additional file 3: Table S3. Nod Factor structure biosynthesized in the presence of $300 \mathrm{mM} \mathrm{NaCl}$ by wild type CIAT 899 and derivatives. (DOC $81 \mathrm{~kb}$ )

Additional file 4: Table S4. Sequences of the primers used in the RT-qPCR and sizes of the PCR products obtained. (DOC $37 \mathrm{~kb}$ )

\section{Competing interests}

The authors declare that they have no competing interests.

\section{Authors' contributions}

Conceived and designed the experiments: MH, FJO, MM. Performed the experiments: all authors. Analyzed the data: all authors. Contributed reagents/materials/analysis tools: MH, FJO, MM. Wrote the paper: PC, APR-S, DFG, MM, FJO, MH. All authors read and approved the final manuscript.

\section{Acknowledgements}

The study was partially supported by AGL2012-38831, Embrapa (02.13.08.001.00.00), CNPq (National Council for Scientific and Technological Development) - Project Science without Borders (400205/2012-5). A.A.P.R.Santos acknowledges a posdoc fellowship from project Science without Borders, D.F.Gomes a PhD fellowship from Project Repensa and A.S.Nakatami a posdoc fellowship from Fundação Araucária. M.H. is also a research fellow from CNPq. We thank the Centro de Investigación, Tecnología e Innovación (CITIUS) of the University of Seville for MS facilities. Approved for publication by the Editorial Board of Embrapa Soja as manuscript 146/2015.

\section{Author details}

'Departamento de Microbiología, Facultad de Biología, Universidad de Sevilla, Avda. Reina Mercedes, 6 Apdo Postal 41012, Sevilla, Spain. 'Embrapa Soja, C.P. 231, 86001-970 Londrina, Paraná, Brazil. ${ }^{3}$ Departamento de Química Orgánica, Facultad de Química, Universidad de Sevilla, Apdo Postal 553, 41071 Sevilla, Spain. ${ }^{4}$ Centro de Investigación Tecnología e Innovación de la Universidad de Sevilla (CITIUS), Avda. Reinas Mercedes, 4B, 41012 Sevilla, Spain.

Received: 26 April 2015 Accepted: 8 October 2015

Published online: 26 October 2015

\section{References}

1. Graham PH, Vance CP. Nitrogen fixation in perspective: an overview of research and extension needs. Field Crops Res. 2000;65:93-106.

2. Hungria M, Loureiro MF, Mendes IC, Campo RJ, Graham PH. Inoculant preparation, production and application. In: Newton WE, editor. Nitrogen fixation: origins, applications an research progress. Dordrech: Springer; 2005. p. 223-2254. doi:10.1007/1-4020-3544-6_11.

3. Ormeño-Orrillo E, Hungria M, Martínez-Romero E. Dinitrogen-fixing prokaryotes. In: Rosemberg E et al., editors. The Prokaryotes - prokaryotic physiology and biochemistry. Berlin Heidelberg: Springer; 2013. p. 427-51. doi:10.1007/978-3-642-30141-4_72.

4. van Hameren B, Hayashi S, Gresshoff PM, Ferguson BJ. Advances in the identification of novel factors required in soybean nodulation, a process critical to sustainable agriculture and food security. J Plant Biol Soil Health. 2013;1:6.
5. Denarié J, Debbelle F, Promé JC. Rhizobium lipo-chitinoligosaccharide nodulation factors: signaling molecules mediating recognition and morphogenesis. Ann Rev Biochem. 1996;65:503-35.

6. Hungria M, Stacey G. Molecular signals exchanged between host plants and rhizobia: basic aspects and potential application in agriculture. Soil Biol Biochem. 1997;29:819-30.

7. Geurts R, Bisseling T. Rhizobium Nod factor perception and signalling. Plant Cell. 2002;14 Suppl:S239-49.

8. Brencic A, Winans SC. Detection of and response to signals involved in host-microbe interactions by plant-associated bacteria. Microbiol Mol Biol Rev. 2005;69:155-94.

9. Oldroyd GE. Speak, friend, and enter: signaling systems that promote beneficial symbiotic associations in plants. Nat Rev Microbiol. 2013;11:252-63.

10. Janczarek M, Rachwal K, Marzec A, Grzadziel J, Palusińska-Szysz M. Signal molecules and cell-surface components involved in early stages of the legume-rhizobium interactions. Appl Soil Ecol. 2015;85:94-113.

11. Kondorosi E, Gyuris J, Schmidt J, John M, Duda E, Hoffmann B, et al. Positive and negative control of nod gene expression in Rhizobium meliloti is required for optimal nodulation. Embo J. 1989;8:1331-40.

12. Spaink HP. Root nodulation and infection factors produced by rhizobial bacteria. Annu Rev Microbiol. 2000:54:257-88.

13. Martínez-Romero E, Segovia L, Mercante FM, Franco AA, Graham P, Pardo MA. Rhizobium tropici, a novel species nodulating Phaseolus vulgaris L. beans and Leucaena sp. trees. Int J Syst Bacteriol. 1991;41:417-26.

14. Hernández-Lucas I, Segovia L, Martínez-Romero E, Pueppke SG. Phylogenetic relationships and host range of Rhizobium spp. that nodulates Phaseolus vulgaris L. Appl Environ Microbiol. 1995;61:2775-9.

15. Hungria M, Andrade DS, Chueire LMO, Probanza A, Guitierrez-Manero FJ, Megías M. Isolation and characterization of new efficient and competitive bean (Phaseolus vulgaris L.) rhizobia from Brazil. Soil Biol Biochem. 2000;21:1515-28.

16. Pinto FGS, Hungria M, Mercante FM. Polyphasic characterization of Brazilian Rhizobium tropici strains effective in fixing $\mathrm{N}_{2}$ with common bean (Phaseolus vulgaris L.). Soil Biol Biochem. 2007;39(8):1851-64.

17. Hungria M, Joseph CM, Phillips DA. Anthocyanidins and flavonols, major nod gene inducers from seeds of a black-seeded common bean (Phaseolus vulgaris L.). Plant Physiol. 1991;97:751-8.

18. Hungria M, Joseph CM, Phillips DA. Rhizobium nod-gene inducers exuded naturally from roots of common bean (Phaseolus vulgaris L.). Plant Physiol. 1991;1991(97):759-64.

19. Poupot R, Martínez-Romero E, Promé JC. Nodulation factors from Rhizobium tropici are sulfated or nonsulfated chitopentasaccharides containing an $\mathrm{N}$-methyl- $\mathrm{N}$-acylglucosaminyl terminus. Biochemistry. 1993:32:10430-5.

20. Morón B, Soria-Díaz ME, Ault J, Verroios G, Noreen S, Rodríguez-Navarro DN, et al. Low pH changes the profile of nodulation factors produced by Rhizobium tropici CIAT899. Chem Biol. 2005:12:1029-40.

21. Estevez J, Soria-Diaz ME, De Cordoba FF, Moron B, Manyani H, Gil A, et al. Different and new Nod factors produced by Rhizobium tropici CIAT899 following $\mathrm{Na}^{+}$stress. FEMS Microbiol Lett. 2009;293:220-31.

22. Guasch-Vidal B, Estévez J, Dardanelli MS, Soria-Díaz ME, de Córdoba FF Balog Cl, et al. High $\mathrm{NaCl}$ concentrations induce the nod genes of Rhizobium tropici CIAT899 in the absence of flavonoid inducers. Mol Plant Microbe Interact. 2013;26:451-60.

23. del Cerro P, Rolla-Santos AAP, Gomes DF, Marks BB, Pérez-Montaño F, Rodríguez-Carvajal MA, et al. Regulatory nodD1 and nodD2 genes of Rhizobium tropici strain CIAT 899 and their roles in the early stages of molecular signaling and host-legume nodulation. BMC Genomics. 2015;16(1):251. doi:10.1186/s12864-015-1458-8.

24. van Rhijn PJS, Feys B, Verreth C, Vanderleyden J. Multiple copies of nodD in Rhizobium tropici CIAT899 and BR816. J Bacteriol. 1993;175:438-47.

25. Ormeño-Orrillo E, Menna P, Gonzaga LA, Ollero FJ, Nicolas MF, Rodrigues EP et al. Genomic basis of broad host range and environmental adaptability of Rhizobium tropici CIAT 899 and Rhizobium sp. PRF 81 which are used in inoculants for common bean (Phaseolus vulgaris L.). BMC Genomics. 2012;13:735.

26. Gomes DF, Batista JSS, Torres AR, Andrade DS, Galii-Terasawa LV, Hungria M. Two-dimensional proteome reference map of Rhizobium tropici PRF 81 reveals several symbiotic determinants and strong resemblance with agrobacteria. Proteomics. 2012;12:1-5.

27. Honma MA, Ausubel FM. Rhizobium meliloti has three functional copies of the nodD symbiotic regulatory gene. Proc Natl Acad Sci U S A. 1987;84:8558-62. 
28. Appelbaum ER, Thompson DV, Idler K, Chartrain N. Rhizobium japonicum USDA 191 has two nodD genes that differ in primary structure and function. J Bacteriol. 1998;170:12-20.

29. Relić B, Fellay R, Lewin A, Perret K, Price NPJ, Rochepeau P, et al. nod genes and Nod factors of Rhizobium species NGR 234. In: New horizons in nitrogen fixation. Dordrecht: Kluwer Academic Publishers; 1993. p. 183-9.

30. Fellay R, Hanin M, Montorzi G, Frey J, Freiberg C, Golinowski W, et al. nodD2 of Rhizobium sp. NGR234 is involved in the repression of the nodABC operon. Mol Microbiol. 1998;27:1039-50.

31. Spaink HP. Rhizobial lipo-oligosaccharides: answers and questions. Plant Mol Biol. 1992;20:977-86

32. Österman J, Marsh J, Laine PK, Zeng Z, Alatalo E, Sullivan JT, et al. Genome sequencing of two Neorhizobium galegae strains reveals a noeT gene responsible for the unusual acetylation of the nodulation factors. BMC Genomics. 2014;15:500

33. Demont N, Arbourel M, Mallet F, Promé D, Ferro M, Promé J-C, et al. The Rhizobium meliloti regulatory nodD3 and syrM genes control the synthesis of a particular class of nodulation factors $\mathrm{N}$-acylated by $(\omega-1)$-hydroxylated fatty acids. EMBO J. 1994;13:2139-48.

34. Gomes DF, Ormeno-Orrillo E, Hungria M. Biodiversity, symbiotic efficiency and genomics of Rhizobium tropici and related species. In: de Bruijn F, editor. Biological nitrogen fixation. New Jersey: Wiley-Blackwell; 2015. p. 747-56.

35. Inui $\mathrm{H}$, Yamaguchi $\mathrm{Y}$, Hirano $\mathrm{S}$. Elicitor actions of $\mathrm{N}$ acetylchitooligosaccharides and laminarioligosaccharides for chitinase and L-phenylalanine ammonia-lyase induction in rice suspension culture. Biosci Biotechnol Biochem. 1997;61:975-8.

36. Liang Y, Cao Y, Tanaka K, Thibivilliers S, Wan J, Choi J, et al. Nonlegumes respond to rhizobial Nod factors by suppressing the innate immune rResponse. Science. 2013;341:1384-7.

37. Miransari M, Smith D. Rhizobial lipo-chitooligosaccharides and gibberellins enhance barley (Hordeum vulgare L.) seed germination. Biotechnol. 2009:8:270-5.

38. Dall'Agnol RF, Ribeiro RA, Ormeño-Orrill E, Rogel MA, Delamuta JRM, Andrade DS, et al. Rhizobium freirei, a symbiont of Phaseolus vulgaris very effective in fixing nitrogen. Int J Syst Evol Microbiol. 2013;63:4167-73.

39. Hungria M, Phillips DA. Effects of a seed color mutation on rhizobial nod-geneinducing flavonoids and nodulation in common bean. Mol Plant-Microbe Interact. 1993;6:418-22

40. Beringer JE. R factor transfer in Rhizobium leguminosarum. J Gen Microbiol. 1974;84:188-98

41. Vincent JM. The modified Fahraeus slide technique. In: A manual for the practical study of root nodule bacteria. Oxford: Blackwell Scientific Publications; 1970

42. Sambrook J, Fritsch EF, Maniatis T. Molecular cloning. In: A laboratory manual. 2nd ed. Cold Spring Harbor NY USA: Cold Spring Harbor Laboratory Press; 1989.

43. Lamrabet $Y$, Bellogín RA, Cubo T, Espuny MR, Gil-Serrano A, Krishnan HB, et al. Mutation in GDP-fucose synthesis genes of Sinorhizobium fredii alters Nod factors and significantly decreases competitiveness to nodulate soybeans. Mol Plant-Microbe Interact. 1999;12:207-17.

44. Schäfer A, Tauch A, Jäger W, Kalinowski J, Thierbach G, Pühler A. Small mobilizable multi-purpose cloning vectors derived from the Escherichia coli plasmids pK18 and pK19: selection of defined deletions in the chromosome of Corynebacterium glutamicum. Gene. 1994;145:69-73.62.

45. Simon R. High frequency mobilization of gram-negative bacterial replicons by the in vivo constructed Tn5-Mob transposon. Mol Gen Genet. 1984;196:413-20.

46. Figurski DH, Helinski DR. Replication of an origin-containing derivative of plasmid RK2 dependent on a plasmid function provided in trans. Proc Natl Acad Sci U S A. 1979;76:1648-52.

47. López-Baena FJ, Monreal JA, Pérez-Montaño F, Guasch-Vidal B, Bellogín RA, Vinardell JM, et al. The absence of Nops secretion in Sinorhizobium fredii HH103 increases GmPR1 expression in Williams soybean. Mol Plant Microbe Interac. 2009;22:1445-54.

48. Pfaffl MW, Horgan GW, Dempfle L. Relative expression software tool (REST) for group-wise comparison and statistical analysis of relative expression results in real-time PCR. Nucleic Acids Res. 2002;30:e36.

49. Dereeper A, Guignon V, Blanc G, Audic S, Buffet S, Chevenet F, et al. Phylogeny.fr: robust phylogenetic analysis for the non-specialist. Nucleic Acids Res. 2008;1:36.

50. Edgar RC. MUSCLE: multiple sequence alignment with high accuracy and high throughput. Nucleic Acids Res. 2004;32(5):1792-7.
51. Castresana J. Selection of conserved blocks from multiple alignments for their use in phylogenetic analysis. Mol Biol Evol. 2000;17(4):540-52.

52. Guindon S, Dufayard JF, Lefort V, Anisimova M, Hordijk W, Gascuel O. New algorithms and methods to estimate maximum-likelihood phylogenies: assessing the performance of PhyML 3.0. Syst Biol. 2010;59(3):307-21.

53. Anisimova M, Gascuel O. Approximate likelihood ratio test for branchs: a fast, accurate and powerful alternative. Syst Biol. 2006;55(4):539-52.

54. Chevenet F, Brun C, Banuls AL, Jacq B, Chisten R. TreeDyn: towards dynamic graphics and annotations for analyses of trees. BMC Bioinformatics. 2006;7:439.

\section{Submit your next manuscript to BioMed Central and take full advantage of:}

- Convenient online submission

- Thorough peer review

- No space constraints or color figure charges

- Immediate publication on acceptance

- Inclusion in PubMed, CAS, Scopus and Google Scholar

- Research which is freely available for redistribution 